\title{
Bio Availability Studies on Ragina \& Energy Protein Rich Food
}

\author{
VIJAY A KHADER ${ }^{1 *}$, ANURADHA ${ }^{2}$ \\ ${ }^{1}$ Former Dean, Faculty of Horne Science, ANGRAU, Rajendranagar, Hyderabad. \\ ${ }^{2}$ Research Associate
}

How to cite this paper: KHADER VA, ANURADHA. (2019) Bio Availability Studies on Ragina \& Energy Protein Rich Food. International Journal of Food Science and Agriculture, 3(3), 173-178.

DOI: $10.26855 /$ ijfsa.2019.09.004

*Corresponding author: VIJAY A KHADER, Former Dean, Faculty of Horne Science, ANGRAU, Rajendranagar, Hyderabad.

Email: vijayakhader@gmail.com

\begin{abstract}
The Horse gram (Dolichos Biflorus) which is commonly used for cattle feed can be diversified for human consumption with less investment. Processed Horse gram flour was prepared using puffing and roasting, processed Soya bean (Glycine max) flour was prepared by dehulling and roasting. The low cost energy protein rich products namely RAGINA and EPRF were prepared using the simple home scale processing methods like germination, roasting and puffing, to improve the nutritional status. Horse gram has been identified as potential food resource for the tropics and also occupies an important place among pulses because of its ability to resist severe drought conditions. Soya bean is one of the best vegetable proteins and has tremendous potential to meet the protein deficiency in the cereal based Indian diets at a low cost. Product development can be taken as income generating activity in the rural areas by the illiterate women. Products can be included in supplementary feeding programmes in order to improve the nutritional status of the vulnerable groups of the population.
\end{abstract}

\section{Keywords}

dolichos Biflorus, soya bean, protein

\section{Introduction}

India is the second most populous country in the world,120 million women live in poverty. As per the National and Regional Survey Prevalence of anemia 74\% in children below 3 years of age, $85 \%$ in pregnant mothers and $90 \%$ among adolescent girls. In a developing country like India, there is a genuine need for nutritious food supplements which can be prepared from readily available raw materials [1]. Since horse gram occupies an important place among the pulse because of its ability to resist severe drought conditions. Horse gram was selected as one of the ingredient in developing mixes. Vitamin A deficiency is prevalent among large segments of the society in many countries [2].

Two different products Ragina and Energy Protein Rich Food (EPRF) were developed incorporating Red palm oil (obtained from the fruits of tree Elaeis guineensis Jacqat) 5\% level which is a rich natural source of $\beta$ carotene. The composition given below.

\begin{tabular}{lcllc}
\hline \multicolumn{2}{c}{ RAGINA } & & & \multicolumn{2}{c}{ EPRF } \\
\cline { 1 - 2 } \cline { 5 - 6 } Ingredients & Amount & & Ingredients & Amount \\
\hline Germinated Ragi Flour & $40 \mathrm{~g}$ & & Dehusked roasted Horse gram flour & $40 \mathrm{~g}$ \\
Puffed Horse gram & $20 \mathrm{~g}$ & & Roasted Soya bean flour & $20 \mathrm{~g}$ \\
Jaggery Powder & $35 \mathrm{~g}$ & & Jaggery Powder & $35 \mathrm{~g}$ \\
Red palm Oil & $05 \mathrm{~g}$ & & Red palm Oil & $05 \mathrm{~g}$ \\
Total & $100 \mathrm{~g}$ & & Total & $100 \mathrm{~g}$ \\
\hline
\end{tabular}




\section{Materials and Methds}

The raw materials used in the preparations of the products such as Ragi and Soyabean were obtained from Regional Agricultural Research Station, Palem, Mahaboobnagar, Horsegram from local market, jaggery powder from Regional Agricultural Research Station, Anakapalli and Red Palm Oil from AP. Co-operative at Seeds Grower's Federation, Pedevagi were obtained.

\subsection{Estimation of minerals, energy and $\beta$ carotene content of developed foods}

The estimates were carried out as per the standard procedures (AO AC, 1983; JH and Tan, 1988)

\subsection{Bio-Availability Studies}

The growth and Bio - Availability Studies (Protein efficiency ratio, overall Digestibility, Nitrogen Growth Index) using wistar strain male albino rats were conducted.

\subsection{Growth \& Protein Efficiency Ratio (PER)}

Weanling male rats 8 per group (wistar strain) were housed individually in cages with wire mesh bottom and fed with diets containing Ragina, casein (control) and ERPF at 10\% of protein. The diets contained following other ingredients i.e. refined groundnut oil (9\%), vitaminised starch 1\% (Chapmen et al 1959), and vitaminised oil 1\% (Hubbell et al, (1937), fibre 4\% and com starch was added to make up to 100 per cent

The diet was stored in closed containers for the duration of the experiment. The diet and water was supplied at ad libitum. The feed was given in especially designed porcelain cups to prevent spillage. The diet was moistened and made into a semi-solid form with the help of warm water. Records of daily food intake were observed and the left over food was collected, dried and weighed for calculating the daily food consumption. Weekly gain in weights of rats were also observed and recorded.

\subsubsection{Protein Efficiency Ratio}

PER of Ragina, EPRF and casein (control) were determined according to the procedure given by Chapman et al (1959)

After PER experimental period, the faeces was collected for 3 days dried to constant weight, powdered and used for nitrogen analysis. Diet intake was also recorded for three days and analysed for nitrogen.

\subsubsection{Overall Digestibility (O.D.)}

Overall digestibility of the developed products \& control was measured using the following formula:

$$
\text { Foodintake(g)-Faeces excreted }(\mathrm{g})
$$

Food intake $(\mathrm{g})$

\subsubsection{Nitrogen Growth Index}

The mean gain in body weight and mean nitrogen intake of the two experimental and control group were plotted on a graph.

\subsubsection{Serum analysis}

The rats were anaesthetized with petroleum either at the end of experiment and blood was collected by decapitation technique. Ventra lateral neck incision was made and jugular vain was located to collect the blood. Serum was separated by centrifuging the blood samples at $3000 \mathrm{rpm}$, for lnvitro quantities' determination of protein, albumin and globulin. The albumin and globulin were calculated using the formula.

$$
\begin{aligned}
& \text { Total Protein }(g \%)=\frac{A \text { of }(T)}{A \text { of }(S)} \times \text { Cone. of Total Protein } \\
& \text { Albumin }(g \%)=\frac{A \text { of }(T)}{A \text { of }(S)} \times \text { Cone. of Albumin } \\
& \text { Globulin }(g \%)=\text { Total Proteins in } g \%-\text { Albumin in } g \%
\end{aligned}
$$




$$
\begin{aligned}
& \text { A } / \text { G Ration }=\frac{\text { Albumin in } \mathrm{g} \%}{\text { Globulin in } \mathrm{g} \%} \\
& \mathrm{~T}=\text { Test } \\
& \mathrm{S}=\text { Standard }
\end{aligned}
$$

\subsection{ORGAN-WEIGHTS}

The animals were dissected and the organs such as liver, kidney and brain were collected and weighed.

\section{Results and Discussions}

\subsection{Mineral, Energy and $\beta$ - carotene content of Developed Foods}

The mineral composition of the developed products (Table 1) showed that the calcium of Ragina (243.66 $\mathrm{mg}$ ) was considerably higher compared to EPRF $(186.31 \mathrm{mg})$. This may be due to the high calcium content of the ragi which is one of the major ingredients in the preparation of Ragina [3].

Table 1. Mineral composition of developed products $(\mathrm{g} / \mathbf{1 0 0 g})$

\begin{tabular}{ccccccccc}
\hline Product & Calcium & Magnesium & Copper & Iron & Zinc & Manganese & Energy (K cal.) & $\boldsymbol{\beta}$-carotene $(\mu \mathrm{g})$ \\
\hline Ragina & $243.66^{*}$ & 116.9 & 0.742 & 4.6 & 1.59 & 4.33 & $397.5^{*}$ & $1070.2^{*}$ \\
EPRF & $186.33^{*}$ & 116.45 & 0.93 & 4.6 & 2.08 & -- & $652.87^{*}$ & $1377.3^{*}$ \\
\hline
\end{tabular}

Statistical analysis by students ' $t$ 'test; *Significantly different at $5 \%$ level

The magnesium, copper and iron contents of both the products developed viz., Ragina and EPRF were similar indicating the values as $116.9 \mathrm{mg}, 0.742 \mathrm{mg}, 4.6 \mathrm{mg}$ for Ragina and $116.4 \mathrm{mg}, 0.93 \mathrm{mg}, 4.6 \mathrm{mg}$ for EPRF respectively. The zinc content of EPRF $2.08 \mathrm{mg}$ was found to be higher when compared to Ragina $1.59 \mathrm{mg}$. The manganese content of Ragina was $4.33 \mathrm{mg}$ while EPRF did not contain manganese. The energy content of EPRF is markedly higher $652.87 \mathrm{Kcal}$ when compared to Ragina $397.5 \mathrm{Kcal}$. This may be due to the use of Soya bean which is rich in fat content. The $\beta$-carotene content of EPRF is $1377.3 \mathrm{mg}$ while in Ragina it is $1070.2 \mathrm{mg}$ [4].

Statistical analysis showed that calcium, Energy and $\beta$ - Carotene values of Ragina are different from EPRF. No significant difference was observed in other minerals. Red Palm oil provides a solution to prevent vitamin A deficiency which is a alarming problem, as it is a concentrated source $(400 \mu \mathrm{g} / \mathrm{g})$ of $\beta$ - carotene, which is a precursor of vitamin A. The present study was undertaken to develop the low cost protein rich products which will be beneficial to improve the nutritional status of the vulnerable group of the population. Study conducted by Vijaya Khader and Aruna ( 2008) to screen the effect of supplementation of Red Palm Oil revealed increase in height \& weight of children. In most of the centers, normal nutrition and grade-1 increased with simultaneous decrease in grade 11 and grade 111 malnutrition [5].

\subsection{Growth and Protein efficiency ratio (PER)}

The gain in weights of rats and PER of the two developed products Ragina and EPRF are given in Table 2, the values are significantly different with each at $5 \%$ level. The weight gain and PER of the rats fed on Ragina was markedly higher $62 . \lg 2.2$ than that observed with EPRF $37.8 \mathrm{~g}$ and 1.0 respectively. The higher weight gain of the rats fed on Ragina might be due to the puffing of horse gram which included sudden heat treatment for short period. The processing increased the PER of protein as it destroys the anti-nutritional factors (Borchers et al, 1947) and results in better utilization of protein. Vijaya Khader and Venkat Rao (1986) reported that cooked dehusked horse gram gave a slightly higher PER than autoclaved whole horsegram. The increase in gain in weight may also be attributed to the germinated ragi used in Ragina. During germination the starch breaks down, which increases amylase and phosphorylase activity in respiratory metabolism and promote digestibility of the sprouted millet. Chandra Shekhar and Chitra (1978) reported the protein quality of germinated horse gram to be higher than that of raw seeds. Similar results were reported by Sudha et al., (1994). 
Table 2. Protein efficiency ratio of Ragina, EPRF (experimental period -4 weeks 8 male rats group)

\begin{tabular}{ccccccccc}
\hline Product & $\begin{array}{c}\text { Weight } \\
\text { Gain(g) }\end{array}$ & $\begin{array}{c}\text { Food } \\
\text { Given (g) }\end{array}$ & $\begin{array}{c}\text { Left Over } \\
\mathbf{( g )}\end{array}$ & $\begin{array}{c}\text { Amount } \\
\text { food } \\
\text { intake(g) }\end{array}$ & $\begin{array}{c}\text { Protein } \\
\text { content of } \\
\text { diet (g\%) }\end{array}$ & $\begin{array}{c}\text { Protein } \\
\text { intake (g) }\end{array}$ & $\begin{array}{c}\text { PER } \\
\text { (Actual) }\end{array}$ & $\begin{array}{c}\text { PER* } \\
\text { (Corrected) }\end{array}$ \\
\hline Ragina & 62.1 & 348 & 102.83 & 265.16 & 6.36 & 16.8 & 3.6 & 2.1 \\
EPRF & 37.1 & 368 & 151.41 & 216.58 & $10.0-$ & 21.0 & 1.7 & 1.1 \\
\hline
\end{tabular}

*The PER of casein was considered as 2.5 for correction. ** Significant at $5 \%$ level

\subsection{Overall Digestibility}

The food intake of rats fed on Ragina and EPRF are $26.77 \mathrm{~g}$ and $28.88 \mathrm{~g}$ and the overall digestibility is $85.69 \%$ and 86.38. No significant difference was observed between these products but they are significantly different from the control diet (Table 3).

Table 3. Overall digestibility of rats fed on developed foods and control

\begin{tabular}{ccccc}
\hline Group & Diet & Food intake (g) & Faecal weight (g) & Overall Digestibility (\%) \\
\hline 1 & Ragina & 26.77 & 3.7 & $85.69 \mathrm{a}$ \\
2 & EPRF & 28.88 & 3.7 & $86.38 \mathrm{a}$ \\
3 & Control ( Casein) & 37.03 & 2.3 & $93.66 \mathrm{~b}$ \\
\hline
\end{tabular}

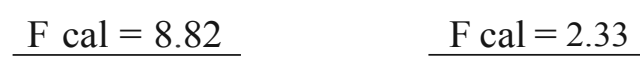

Statistical analysis of variability in the data by ' $\mathrm{F}$ ' ration at 5\% level Values not sharing common superscript letters are significantly different

\subsection{Nitrogen - Growth Index}

This index is used to obtain a curve which indicate the gain in body weight for the nitrogen intake. Similar studies were conducted by Allison et al., (1955). The values are represented in Table 4.

Table 4. Nitrogen growth index

\begin{tabular}{ccc}
\hline Product & Gain in weight (g) & Nitrogen intake (g) \\
\hline Ragina & 61.2 & 2.68 \\
EPRF & 42.9 & 3.45 \\
Control (Casein Casein) & 117.1 & 4.68 \\
\hline
\end{tabular}

Although the nitrogen intake of the rats fed on the diet Ragina $(2.68 \mathrm{~g})$ was comparatively lower than that of EPRF (3.45g) the weight gain was higher in case of Ragina a (61.2 g). Reduced gain in weight of the rats fed on EPRF (42.9 g) may be due to the anti nutritional factors present in the soybean which might have interfered with the protein utilization. The better gain in weight of Ragina was due to processing like germination and puffing of ragi and horse gram incorporated in the preparation of the product which might have increased the protein utilization [6].

\subsection{Organ weights}

The weights of different organs collected from the rats fed on Ragina, EPRF and control diet for a period of 5 weeks are given in Table 5. The group of rats fed on Ragina gained maximum weight (61.2 g) as compared to rats fed on 
EPRF (42.9 g). However, the body weights of rats fed on Ragina comparatively less as compared to rats fed on casein diet at $10 \%$ level. This may be due to the less protein content of Ragina.

Table 5. Mean weight of various organs of rats fed on ragina, EPRF and control (duration of experiment -5weeks; 8 male rats per group)

\begin{tabular}{cccccccc}
\hline \multirow{2}{*}{ Group } & \multicolumn{2}{c}{ Mean body weight } & & \multicolumn{3}{c}{ Gain weight $(\mathrm{g})$} \\
\cline { 2 - 3 } \cline { 5 - 7 } \cline { 5 - 7 } & Initial & Final & & Brain & Liver & Kidney \\
\hline Ragina & 32.4 & 93.6 & & 61.2 & & 5.3 & 1.10 \\
EPRF & 32.6 & 75.5 & & 42.9 & & 3.87 & 1.4 \\
Control & 32.5 & 149.7 & & 117.2 & & 7.6 & 1.6 \\
\hline
\end{tabular}

The rats fed on EPRF showed markedly less gain in body weight as compared with Ragina and casein diets in spite of $10 \%$ protein. This may be due to the variety of Soyabean used and also the anti-nutritional factors present in that particular variety. Similar type of results are observed in the case of liver weights.

The weights of the kidney and brain of rats fed on EPRF are comparable to that of rats fed on casein diet. Whereas, the kidney as well as brain weights of rats fed on Ragina are much lower as compared to rats fed on EPRF and casein diets. This may be due to the less protein contents of the Ragina diet.

\subsection{Serum Analysis}

There is no significant difference between the developed products (Table 6) with regard to total protein, albumin, globulin and $A I G$ ration; but markedly different from control group.

Table 6. The mean protein, albumin, globulin and $A / G$ ratio

\begin{tabular}{ccccc}
\hline & \multicolumn{4}{c}{ Mean total protein, Albumin, globulin and A/G ration of serum of rats } \\
& Total protein $(\mathbf{g})$ & Albumin $(\mathbf{g})$ & Globulin $(\mathbf{g})$ & A/G ration \\
\hline Ragina & 4.5 & 2.6 & 1.8 & 1.6 \\
EPRF & 4.4 & 2.5 & 1.8 & 1.6 \\
Control & 5.0 & 3.2 & 1 & 2.2 \\
\hline
\end{tabular}

\subsection{Summary}

PER of Ragina higher than EPRF. This might be due to the puffed horse gram used in the preparation of Ragina. Puffing makes the pulse very light and easy to digest due to the breakage of protein into simpler amino acids indicating the beneficial effect of puffing. No difference was observed in the overall digestibility of developed products. Though the nitrogen intake of the rats fed on the diets Ragina was comparatively lower than that of EPRF the weight gain was higher in case of Ragina. Reduced gain in weight of the rats fed on EPRF may be due to the anti nutritional factors present in the soya bean which might have interfered with the protein utilization. The better gain in weight of Ragina was due to processing like germination and puffing of ragi and horse gram incorporated in the preparation of this product which might have increased the protein utilization [7].

The weights of the kidney and brain of the rats fed on EPRF are comparable to that of rats fed on casein diet. Whereas, the kidney as well as brain weights of rats fed on Ragina are much lower as compared to rats fed on EPRF and casein diets. This may be due to the less protein content of the Ragina diet [8].

The purpose of the present study was to investigate the bioavailability of the Red Palm oil incorporated mixes developed using horse gram, ragi and soya bean. Crude Palm Oil is Nature's richest source of the carotenoid with concentrations in 
the order of 700-1000 ppm. This is about 30 times more than what is present in carrots. Product development is a new approach to overcome Vitamin A deficiency in many parts of the developing world [9-10].

\section{ACKNOWLEDGEMENT}

The authors are thankful to ICAR New Delhi for providing financial support in conducting the study.

\section{REFERENCES}

[1] Allison. J.B. (1955), physical Rev., 35,664

[2] Association of official agricultural chemists (1983), official methods of analysis, ( AOAC) Washington; 21-26

[3] Borchers, R.: Ackerson. C.W.: Sandstedt, RM., (1947), Trypsin inhibitor ID. Determination and heat destruction of the trypsin inhibitor of soyabeans. Archs Biochem 12:367 - 374.

[4] Chandrasekhar, V and Chitta S. (1978), Evaluation of protein quality of sprouted Horse gram and Green gram on albino rat. Ind. J. Nutr.Dietet. 15(7).

[5] Chapmen, D.G.; Castillo, R; Campbell, J.A., (1959), Evaluation of protein in foods I. A method for the determination of protein efficiency ration. Can. J. Biochemistry, Physiol: $37: 679-686$.

[6] Hubbel, RB., Mendal, L.B. and Wakeman. A.J., (1937), A new salt mixture for use in experimental diets J.Nutr., 14,273.

[7] Ng JH and Tan B (1988); Analysis of palm oil carotenoids by HPCL with diode array detection. J.Clin.Sci., 26: $463-69$

[8] Sudha, N;Mushtari begum, J; Vijayalakshmi D. and Annapurna, M.J,(1994), Protein quality an utilization of Horse gram in selected Products, Beverage \& food world. Pg:23\& 24.

[9] Vijaya khader and Venkat Rao (1986) limiting amino acids horse gram 13 (6) 158 Ind. J Nutr. \& Dietic.

[10] Vijaya Khader and Aruna (2008) Operational feasibility of introducing RPO into the feeding programs in urban ICDS centers. Natural Product Radiances ,.7 (4).310-313 